\title{
Partial rescue of in vivo insulin signalling in skeletal muscle by impaired insulin clearance in heterozygous carriers of a mutation in the insulin receptor gene
}

\author{
K. Højlund • J. F. P. Wojtaszewski • J. Birk • \\ B. F. Hansen $\cdot$ H. Vestergaard $\cdot$ H. Beck-Nielsen
}

Received: 28 February 2006 / Accepted: 24 April 2006/ Published online: 8 June 2006

(C) Springer-Verlag 2006

\begin{abstract}
Aims/hypothesis Recently we reported the coexistence of postprandial hypoglycaemia and moderate insulin resistance in heterozygous carriers of the Arg1174Gln mutation in the insulin receptor gene (INSR). Controlled studies of in vivo insulin signalling in humans with mutant INSR are unavailable, and therefore the cellular mechanisms underlying insulin resistance in Arg1174Gln carriers remain to be clarified.

Subjects, materials and methods We studied glucose metabolism and insulin signalling in skeletal muscle from six Arg1174Gln carriers and matched control subjects during a euglycaemic-hyperinsulinaemic clamp.
\end{abstract}

\footnotetext{
K. Højlund $\cdot$ H. Beck-Nielsen

Diabetes Research Centre, Department of Endocrinology,

Odense University Hospital,

Odense, Denmark

J. F. P. Wojtaszewski • J. Birk

Copenhagen Muscle Research Centre,

Institute of Exercise and Sport Sciences,

Department of Human Physiology,

University of Copenhagen,

Copenhagen, Denmark

B. F. Hansen

Diabetes Biology, Novo Nordisk,

Bagsvaerd, Denmark

H. Vestergaard

Department of Endocrinology, Herlev Hospital,

University of Copenhagen,

Copenhagen, Denmark

K. Højlund $(\bowtie)$

Department of Endocrinology, Odense University Hospital,

Kloevervaenget 6 ,

DK-5000 Odense C, Denmark

e-mail: k.hojlund@dadlnet.dk
}

Results Impaired clearance of exogenous insulin caused four-fold higher clamp insulin levels in Arg1174Gln carriers compared with control subjects $(p<0.05)$. In Arg1174Gln carriers insulin increased glucose disposal and non-oxidative glucose metabolism $(p<0.05)$, but to a lower extent than in controls $(p<0.05)$. Insulin increased Akt phosphorylation at Ser473 and Thr308, inhibited glycogen synthase kinase- $3 \alpha$ activity, reduced phosphorylation of glycogen synthase at sites $3 a+3 b$, and increased glycogen synthase activity in Arg1174Gln carriers (all $p<0.05)$. In the insulin-stimulated state, Akt phosphorylation at Thr308 and glycogen synthase activity were reduced in Arg1174Gln carriers compared with controls $(p<0.05)$, whereas glycogen synthase kinase- $3 \alpha$ activity and phosphorylation of glycogen synthase at sites $3 a+3 b$ were similar in the two groups.

Conclusions/interpretation In vivo insulin signalling in skeletal muscle of patients harbouring the Arg1174Gln mutation is surprisingly intact, with modest impairments in insulin-stimulated activity of Akt and glycogen synthase explaining the moderate degree of insulin resistance. Our data suggest that impaired insulin clearance in part rescues in vivo insulin signalling in muscle in these carriers of a mutant $I N S R$, probably by increasing insulin action on the non-mutated insulin receptors.

Keywords Glucose metabolism · Glycogen synthase . Insulin clearance $\cdot$ Insulin receptor mutation . Insulin signalling

\section{Abbreviations}

$\begin{array}{ll}\text { CHO } & \text { Chinese hamster ovary } \\ \text { G6P } & \text { glucose-6-phosphate } \\ \text { GDR } & \text { glucose disposal rate } \\ \text { GSK-3 } & \text { glycogen synthase kinase-3 }\end{array}$




$\begin{array}{ll}\text { HRP } & \text { horseradish peroxidase } \\ \text { HSP90 } & \text { heat shock protein } 90 \\ \text { mt } & \text { mutant } \\ \text { INSR } & \text { insulin receptor gene } \\ \text { IRS } & \text { insulin receptor substrate } \\ \text { IRTK } & \text { insulin receptor tyrosine kinase } \\ \text { NOGM } & \text { non-oxidative glucose metabolism } \\ \text { PI3K } & \text { phosphoinositide 3-kinase } \\ \text { SLC2A4 } & \text { solute carrier family 2 (facilitated glucose } \\ & \text { transporter), member 4 (previously known as } \\ & \text { GLUT4) } \\ \text { TBST } & \text { Tris-buffered saline with Tween 20 } \\ \text { wt } & \text { wild-type }\end{array}$

\section{Introduction}

Mutations in the human insulin receptor gene (INSR) have been discovered almost exclusively by sequencing this gene in patients with syndromes of severe insulin resistance [1]. Studies of these naturally occurring mutations of INSR using cell lines have provided valuable insights into the relationship between the structure and function of the receptor and have contributed to the understanding of the molecular mechanism involved in insulin signalling and insulin resistance $[1,2]$. Mutations in the insulin receptor tyrosine kinase (IRTK) domain are characterised by decreased IRTK activity despite normal binding and affinity of insulin for the receptor $[1,2]$. These mutations appear to cause insulin resistance in a dominant fashion, unlike mutations in other domains of the INSR. The dominant negative effect may result from the heterotetrameric $\left(\alpha_{2} \beta_{2}\right)$ structure of the insulin receptor. Thus, of the three forms of heterotetramer formed in patients heterozygous for a single mutant allele, only insulin receptors formed by the two wild-type (wt) alleles - the wt/wt receptors - are expected to be fully functional $[1,2]$.

We have recently reported a novel syndrome of autosomal dominant hyperinsulinaemic hypoglycaemia in three generations of a family [3]. All ten family members affected by hypoglycaemia carried a heterozygous mutation in the IRTK domain of INSR (Arg1174Gln). This mutation has previously been found in three females with the type A syndrome of insulin resistance, and in an apparently healthy male [4-7]. Complete cosegregation (logarithm of the odds score 3.21) with the disease phenotype supported the proposition that the Arg1174Gln mutation was the cause of hypoglycaemia [3]. In addition to hypoglycaemia in the postprandial state, the Arg1174Gln carriers were physiologically characterised by moderate insulin resistance and impaired clearance of insulin. However, none of these subjects had type 2 diabetes [3]. This suggests preserved ability to compensate for insulin resistance.
Insulin stimulation of glycogen synthesis is believed to involve insulin receptor autophosphorylation, activation of insulin receptor substrates (IRSs), phosphoinositide 3kinase (PI3K) and protein kinase Akt, which in turn leads to inhibition of glycogen synthase kinase-3 (GSK-3), and hence activation of glycogen synthase by decreasing phosphorylation at regulatory sites, of which the $\mathrm{COOH}$ terminal residues Ser640 (site 3a) and Ser644 (site 3b) are probably the most important $[8,9]$. In patients with type 2 diabetes, failure of insulin to activate glycogen synthase is a hallmark feature of skeletal muscle insulin resistance [1015]. However, despite reports of impaired activation of PI3K by insulin [14-16], most studies have failed to demonstrate impaired insulin signalling downstream of PI3K, including activation of Akt, inhibition of GSK-3 and dephosphorylation of glycogen synthase at sites $3 a+3 b$ in muscle from subjects with type 2 diabetes both in vivo and in vitro $[10,15,17,18]$. Recently, impaired activation of glycogen synthase in type 2 diabetes was linked to increased phosphorylation at $\mathrm{NH}_{2}$-terminal residues Ser7 (site 2) and Ser10 (site 2a), suggesting that other pathways downstream of the insulin receptor could be involved [10]. In cell lines transfected with the Arg1174Gln mutation and thus expressing the mutant INSR in a homozygous state, insulin in physiological concentrations $(1,000 \mathrm{pmol} / \mathrm{l})$ showed impaired ability to increase tyrosine phosphorylation of IRS-1, PI3K activity, solute carrier family 2 (facilitated glucose transporter), member 4 (SLC2A4, previously known as GLUT4) translocation and glycogen synthesis $[7,19]$. However, controlled studies of the effects of the Arg1174Gln mutation or other mutations in INSR on downstream insulin signalling in skeletal muscle in humans in vivo are unavailable.

The present study was undertaken to elucidate the molecular mechanisms underlying insulin resistance in heterozygous carriers of the Arg1174Gln mutant INSR. Such carriers are an in vivo model of moderate insulin resistance apparently without type 2 diabetes, and we investigated the effects of insulin on glucose metabolism, downstream insulin signalling and phosphorylation of glycogen synthase in their skeletal muscle, compared with matched healthy control subjects.

\section{Subjects, materials and methods}

\section{Study subjects}

Clinical and genetic data have been reported previously [3]. Six family members carrying the Arg1174Gln mutation and six healthy control subjects, matched for age, sex and BMI, participated in the study (Table 1). The Arg1174Gln carriers all suffered from episodes of hypoglycaemia in the 
Table 1 Clinical and biochemical characteristics

\begin{tabular}{lccc}
\hline & Control group & Arg1174Gln group & $p$ value \\
\hline Male/female & $5 / 1$ & $5 / 1$ & $\mathrm{~ns}$ \\
Age (years) & $44.0 \pm 2.3$ & $41.7 \pm 5.6$ & $\mathrm{~ns}$ \\
BMI $\left(\mathrm{kg} / \mathrm{m}^{2}\right)$ & $24.5 \pm 0.8$ & $25.4 \pm 1.0$ & $\mathrm{~ns}$ \\
$\mathrm{HbA}_{1 \mathrm{c}}(\%)$ & $4.8 \pm 0.1$ & $5.7 \pm 0.2$ & $<0.01$ \\
Total cholesterol $(\mathrm{mmol} / \mathrm{l})$ & $5.2 \pm 0.3$ & $5.7 \pm 0.4$ & $\mathrm{~ns}$ \\
Plasma triglycerides $(\mathrm{mmol} / \mathrm{l})$ & $1.2 \pm 0.4$ & $1.3 \pm 0.2$ & $\mathrm{~ns}$ \\
Basal plasma glucose $(\mathrm{mmol} / \mathrm{l})$ & $5.3 \pm 0.1$ & $5.6 \pm 0.1$ & $\mathrm{~ns}$ \\
Clamp plasma glucose $(\mathrm{mmol} / \mathrm{l})$ & $5.1 \pm 0.1$ & $5.3 \pm 0.1$ & $\mathrm{~ns}$ \\
Basal serum insulin $(\mathrm{pmol} / \mathrm{l})$ & $18 \pm 2$ & $177 \pm 31$ & $<0.01$ \\
Clamp serum insulin $(\mathrm{pmol} / \mathrm{l})$ & $328 \pm 17$ & $1313 \pm 127$ & $<53 \pm 64$ \\
Basal serum C-peptide $(\mathrm{pmol} / \mathrm{l})$ & $403 \pm 46$ & $527 \pm 101$ & $\mathrm{~ns}$ \\
Clamp serum C-peptide $(\mathrm{pmol} / \mathrm{l})$ & $465 \pm 83$ & $192 \pm 45$ & $\mathrm{~ns}$ \\
Insulin clearance $\left(\mathrm{ml} / \mathrm{min} \mathrm{per} \mathrm{m}^{2}\right)$ & $885 \pm 132$ & & $<0.01$ \\
\hline
\end{tabular}

Data are mean \pm SEM

ns Not significant

postprandial state and all were without diabetes and showed no clinical features of severe insulin resistance. The control subjects had normal glucose tolerance and no family history of diabetes. All subjects had normal results of screening blood tests of hepatic and renal function. All subjects were instructed to refrain from strenuous physical activity for $48 \mathrm{~h}$ before the experiment. Informed consent was obtained from all subjects before participation. The study was approved by the Local Ethics Committee and performed in accordance with the Declaration of Helsinki-II.

\section{Study design}

All study subjects were admitted to the Diabetes Research Centre at Odense University Hospital, Denmark. After a 10-h overnight fast, the subjects underwent a euglycaemichyperinsulinaemic clamp $(2-\mathrm{h}$ equilibrium period followed by $3 \mathrm{~h}$ of insulin infusion, $40 \mathrm{mU} / \mathrm{m}^{2}$ per $\mathrm{min}$ ) combined with indirect calorimetry and muscle biopsies. Refer to our previous report [3] for further details about calculation of glucose disposal rate (GDR), glucose oxidation, nonoxidative glucose metabolism (NOGM) and insulin clearance. Plasma glucose, serum insulin, C-peptide and NEFA were measured as described previously [20]. Muscle biopsies were obtained from the vastus lateralis muscle before and after the insulin infusion period using a modified Bergström needle with suction under local anaesthesia (10 ml lidocaine 2\%). Muscle samples were immediately blotted free of blood, fat and connective tissue and frozen in liquid nitrogen within 20-30 s.

Muscle lysate

Muscle tissue was freeze-dried and dissected free of visual blood, fat and connective tissues. Muscle lysate was prepared by homogenisation of muscle tissue (1:80, weight:volume) in a buffer containing $50 \mathrm{mmol} / 1$ HEPES (pH 7.5), $150 \mathrm{mmol} / 1 \mathrm{NaCl}, 20 \mathrm{mmol} / \mathrm{l} \mathrm{Na}$-pyrophosphate, $20 \mathrm{mmol} / 1 \beta$-glycerophosphate, $10 \mathrm{mmol} / \mathrm{l} \mathrm{NaF}, 2 \mathrm{mmol} /$ 1 Na-orthovanadate, $2 \mathrm{mmol} / \mathrm{l}$ EDTA, 1\% Nonidet P-40, $10 \%$ glycerol, $2 \mathrm{mmol} / \mathrm{l}$ phenylmethylsulfonyl fluoride, $1 \mathrm{mmol} / 1 \mathrm{MgCl}_{2}, 1 \mathrm{mmol} / 1 \mathrm{CaCl}_{2}, 10 \mu \mathrm{g} / \mathrm{ml}$ leupeptin, $10 \mu \mathrm{g} / \mathrm{ml}$ aprotinin and $3 \mathrm{mmol} / 1$ benzamidine. Homogenates were rotated end over end for $1 \mathrm{~h}$ at $4^{\circ} \mathrm{C}$, and then cleared by centrifugation at $17,500 \mathrm{~g}$ at $4^{\circ} \mathrm{C}$ for $1 \mathrm{~h}$. Protein content in the supernatant was measured by the bicinchoninic acid method (Pierce Chemical Company, Rockford, IL, USA).

Protein content and protein phosphorylation

Muscle lysate proteins were boiled in Laemmli buffer, separated using $7.5 \%$ or $10 \%$ Bis-Tris gels (Invitrogen, Taastrup, Denmark) (HCl-Tris gels; Biorad, Copenhagen, Denmark), and transferred (semidry) to PVDF membranes (Immobilon Transfer Membrane; Millipore, Glostrup, Denmark). After blocking (Tris-buffered saline with Tween 20 $[\mathrm{TBST}]+1 \%$ skimmed milk overnight at $\left.4^{\circ} \mathrm{C}\right)$, the membranes were incubated with primary antibodies (TBST $+1 \%$ skimmed milk, $2 \mathrm{~h}$ at room temperature) followed by incubation in horseradish peroxidase (HRP)-conjugated secondary antibody (TBST $+1 \%$ skimmed milk, $1 \mathrm{~h}$ at room temperature). Following detection (ECl+; Amersham Biosciences, Hillerød, Denmark) and quantification using a CCD image sensor and 1D software (Kodak Image Station, E440CF; Kodak, Glostrup, Denmark), the protein content was expressed in arbitrary units relative to a human skeletal muscle standard. The primary antibodies used were antiIRS-1 (no. 06-248), anti-p85 (no. 06-497) and anti-Akt-1/ PKB (no. 06-558) (Upstate Biotechnology, Lake Placid, MA, USA). The rabbit anti-glycogen synthase antibody 
[21] was provided by O. Pedersen (Steno Diabetes Center, Gentofte, Denmark). The insulin receptor monoclonal antibody CT3 was raised against the $\mathrm{COOH}$-terminal of the $\beta$-subunit and was a gift from K. Siddle (Cambridge University, Cambridge, UK). The phospho-specific antibodies used were anti-pAkt Ser473 (New England Biolabs, USA, no. 9271) and anti-pAkt Thr308 (06-801; Upstate Biotechnology). The sheep antibodies to anti-pGS site 2, anti-pGS site $3 a+3 b$ and anti-pGS site $2+2 a$ were generated as described previously [10]. The secondary antibodies used were goat anti-rabbit HRP (P0448), goat-anti-mouse HRP (P0447) and rabbit-anti-sheep HRP (P0163) (Dako, Glostrup, Denmark).

\section{IRTK and PI3K activity}

IRTK activity was measured in muscle lysate after immunopurification of insulin receptor (anti-IR) (AB3; Oncogene Science, Cambridge, MA, USA) using a microtitre assay as described previously [22]. IRS-1-associated PI3K activity was measured in muscle lysate after immunopurification of IRS-1 (anti-IRS-1) (catalogue no. 06-248; Upstate Biotechnology) as described previously [10].

\section{Akt1 and Akt2 activity}

Sequential immunopurification of first Akt2 (anti-Akt2) (catalogue no. 06-606; Upstate Biotechnology) and then Akt1 (anti-Akt1) (catalogue no. 06-558; Upstate Biotechnology) was performed using $400 \mu \mathrm{g}$ of muscle lysate protein before measuring Akt kinase activity. The prior depletion of Akt2 protein was necessary to avoid co-immunopurification of both Aktl and Akt 2 using the anti-Akt1 from Upstate Biotechnology. The immunopurification (overnight at $4^{\circ} \mathrm{C}$ ) was performed using G-Sepharose beads suspended in lysate buffer. The pellet was washed three times in a buffer containing $20 \mathrm{mmol} / \mathrm{l}$ Tris $(\mathrm{pH}$ 7.4), $5 \mathrm{mmol} / \mathrm{l}$ EDTA, $10 \mathrm{mmol} / 1 \mathrm{Na}_{4} \mathrm{P}_{2} \mathrm{O}_{7}, 100 \mathrm{mmol} / \mathrm{l} \mathrm{NaF}, 1 \% \mathrm{NP}-40$ and $3 \mathrm{mmol} / \mathrm{l} \mathrm{Na}_{3} \mathrm{VO}_{4}$ and twice in a buffer containing $20 \mathrm{mmol} / \mathrm{l} \mathrm{Tris}\left(\mathrm{pH} 7.4\right.$ ), $10 \mathrm{mmol} / 1 \mathrm{MgCl}_{2}$ and $1 \mathrm{mmol} /$ 1 dithiothreitol. The kinase activity assay was run in a buffer containing $50 \mathrm{mmol} / \mathrm{l}$ Tris (pH 7.4), $10 \mathrm{mmol} / 1 \mathrm{MgCl}_{2}$, $1 \mathrm{mmol} / \mathrm{l}$ dithiothreitol and $1 \mu \mathrm{mol} / \mathrm{l}$ protein kinase inhibitor (catalogue no. P-0300; Sigma-Aldrich, St Louis, MO, USA) using $30 \mu \mathrm{mol} / \mathrm{l} \mathrm{Akt/SGK}$ substrate peptide (catalogue no. 12-340; Upstate Biotechnology) and (111 kBq per sample) ${ }^{32} \mathrm{P} \gamma$-ATP (Perkin Elmer, Boston, MA, USA) as substrates. The kinase assay was run for $30 \mathrm{~min}$ at $30^{\circ} \mathrm{C}$ before the reaction was stopped by addition of a buffer containing $0.6 \%$ $\mathrm{HCl}, 1 \mathrm{mmol} / \mathrm{l}$ ATP and 1\% BSA. Aliquots of reaction mixture were spotted on p81 filter paper, washed in $75 \mathrm{mmol} / \mathrm{l}$ phosphoric acid and dried using acetone before determination of ${ }^{32} \mathrm{P}$ content by liquid scintillation counting.
GSK- $3 \alpha$ and GSK-3 $\beta$ activity

GSK-3 $\alpha$ was immunoprecipitated from muscle lysate using an anti-GSK- $3 \alpha$ antibody (Upstate Biotechnology) bound to protein G-Sepharose. The supernatant from this immunoprecipitation was then added to new protein G-Sepharose and anti-GSK-3 $\beta$ antibody (Transduction Laboratories, BD Biosciences, San Jose, CA, USA). Kinase activity was measured in both immunoprecipitates in a buffer containing $8 \mathrm{mmol} / \mathrm{l}$ MOPS (pH 7.0), $10 \mathrm{nmol} / \mathrm{l}$ microcystin, $200 \mu \mathrm{mol} / 1$ EDTA, $0.5 \mathrm{mmol} /$ $1 \mathrm{Na}_{3} \mathrm{VO}_{4}, 10 \mathrm{mmol} / \mathrm{l} \mathrm{Mg}$ acetate and $125 \mu \mathrm{mol} / \mathrm{l}$ ATP using $20 \mu \mathrm{mol} / 1$ phospho-GS2-peptide (YRRAAV PPSPSLSRHSSPHQSpEDEEE [Sp=phosphoserine]; Schafer-N, Copenhagen, Denmark) as substrate and (55.5 kBq per sample) ${ }^{32} \mathrm{P} \gamma$-ATP (Perkin Elmer). The kinase assay was run for $60 \mathrm{~min}$ at $30^{\circ} \mathrm{C}$ before the reaction was stopped by spotting $30 \mu$ onto $\mathrm{p} 81$ filter paper. The preparation was washed in $75 \mathrm{mmol} / \mathrm{l}$ phosphoric acid and dried with acetone before determination of ${ }^{32} \mathrm{P}$ content by liquid scintillation counting.

Glycogen synthase activity

Activity was measured in homogenates by a method described previously [23]. Glycogen synthase activity was determined in the presence of 0.02 and $8 \mathrm{mmol} / 1$ glucose-6phosphate (G6P) and expressed either as the percentage of G6P-independent glycogen synthase activity (I-form activity) (100 times the activity in the presence of $0.02 \mathrm{mmol} /$ 1 G6P divided by the activity at $8 \mathrm{mmol} / \mathrm{l} \mathrm{G6P}$ [saturated]) or as total glycogen synthase activity.

\section{SLC2A4 protein in total crude membranes}

Freeze-dried muscle was homogenised (1:110, weight: volume) in a buffer containing $250 \mathrm{mmol} / \mathrm{l}$ sucrose, $30 \mathrm{mmol} / \mathrm{l}$ HEPES, $2 \mathrm{mmol} / \mathrm{l}$ EGTA, $40 \mathrm{mmol} / \mathrm{l} \mathrm{NaCl}$, $2 \mathrm{mmol} / \mathrm{l}$ phenylmethylsulfonyl fluoride and $\mathrm{pH} 7.4$ using a Polytron PT 3100 (Kinematica, Littau-Luzern, Switzerland) and spun at $200,000 \mathrm{~g}$ for $60 \mathrm{~min}$ at $4^{\circ} \mathrm{C}$ using a TL-100 ultracentrifuge (Beckman Coulter, Fullerton, CA, USA). The resulting pellet (corresponding to the membrane fraction) was resuspended by short-term sonication (50 mmol/1 Tris, 4\% SDS, $1 \mathrm{mmol} / 1$ EDTA, pH 7.4) and cleared by centrifugation at $4,000 \mathrm{~g}$ for $1 \mathrm{~min}$. SLC2A 4 protein was determined by western blotting as described above (blocking: TBST $+2 \%$ skim milk overnight at $4{ }^{\circ} \mathrm{C}$; primary antibody: anti-GLUT4 antibodies [no. AB1346; Chemicon, Temecula, CA, USA] in TBST $+2 \%$ skim milk for $2 \mathrm{~h}$ at room temperature; HRP-conjugated secondary antibody: goat anti-rabbit HRP [P0448] in 2\% skim milk for $1 \mathrm{~h}$ at room temperature). 


\section{Statistical analysis}

Calculations and statistical analysis were performed using SSSP for Windows version 10.0. Data are presented as mean \pm SEM. Differences between and within groups were evaluated using the Mann-Whitney $U$-test for unpaired data and the Wilcoxon signed ranks test for paired data, respectively (two-sided). Significance was accepted at the $p<0.05$ level.

\section{Results}

Euglycaemic-hyperinsulinaemic clamp

Family members carrying the Arg1174Gln mutation (Arg1174Gln group) had higher $\mathrm{HbA}_{1 \mathrm{c}}$ levels than the controls, but all values were within the normal range (Table 1). Data obtained from the euglycaemic-hyperinsulinaemic clamp studies have been reported previously [3]. Basal levels of plasma glucose and serum C-peptide were similar, and C-peptide was unaffected by insulin infusion in both groups (Table 1). Basal serum insulin levels were higher in the Arg1174Gln group than in the controls. Insulin infusion at a rate of $40 \mathrm{mU} / \mathrm{m}^{2}$ per min raised serum insulin to 4-fold higher levels in the Arg1174Gln group compared with control subjects. This was caused by markedly reduced clearance of insulin in the Arg1174Gln group.

Basal GDR, glucose oxidation and NOGM were similar in the two groups. In both groups, GDR, glucose oxidation and NOGM increased in response to insulin infusion (Table 2). However, during the insulin-stimulated state GDR and NOGM in the Arg1174Gln group were lower than in the control group. The lower GDR was almost exclusively ( $87 \%$ of the reduction) accounted for by impaired insulin stimulation of NOGM.
Proximal insulin signalling

In the total population $(n=12)$, insulin infusion caused an increase in both IRTK $(7.02 \pm 0.86$ vs $9.63 \pm 0.73$ arbitrary units; $p=0.04$ ) and IRS-1-associated PI3K activity (72.0土 11.4 vs $107.5 \pm 16.5$ arbitrary units; $p=0.05)$. Insulin infusion caused similar increases in IRTK activity in the control (42\%) and Arg1174Gln (33\%) groups, but in neither of the groups did this achieve statistical significance (Fig. 1a). In control subjects, insulin infusion increased IRS-1-associated PI3K activity, whereas in the Arg1174Gln group no significant response to insulin was observed $(p=0.46)$ (Fig. 1b). However, there was no difference between the groups in IRS-1-associated PI3K activity in either the basal or the insulin-stimulated state.

In the control subjects, insulin infusion increased phosphorylation of Akt at Thr308 and Ser473 as well as Akt1 and Akt2 activity (Fig. 1c-f). In the Arg1174Gln group, insulin infusion also increased phosphorylation of Akt at Ser473 and Thr308, whereas Akt1 $(p=0.08)$ and Akt2 $(p=0.08)$ tended to be increased by insulin. However, insulin-stimulated Thr308 phosphorylation and Akt2 activity were reduced in the Arg1174Gln group compared with the control group. Insulin-stimulated Akt1 activity also tended to be reduced in the Arg1174Gln group $(p=0.09)$, whereas no difference in Ser473 phosphorylation was observed $(p=0.59)$.

Downstream insulin signalling

In the total population $(n=12)$, insulin infusion inhibited GSK $-3 \alpha$ activity $\left(0.111 \pm 0.013\right.$ vs $0.071 \pm 0.007 \mathrm{pmol} \mathrm{min}^{-1}$ $\left.\mathrm{mg}^{-1} ; p=0.01\right)$ and tended to reduce GSK-3 $\beta$ activity $\left(0.760 \pm 0.039\right.$ vs $\left.0.654 \pm 0.042 \mathrm{pmol} \mathrm{min}^{-1} \mathrm{mg}^{-1} ; p=0.07\right)$. No differences in either GSK-3 $\alpha$ or GSK-3 $\beta$ activity were observed between the groups (Fig. 2a,b). In the Arg1174Gln group, insulin infusion caused a reduction in GSK-3 $\alpha$ activity, whereas in the control group insulin

Table 2 Euglycaemic-hyperinsulinaemic clamp data

\begin{tabular}{lcc}
\hline & Control group & Arg1174Gln group value \\
\hline GDR in basal condition & $77 \pm 4$ & $76 \pm 3$ \\
GDR during clamp & $346 \pm 33^{\mathrm{a}}$ & $200 \pm 34^{\mathrm{a}}$ \\
Glucose oxidation in basal condition & $45 \pm 6$ & $48 \pm 6$ \\
Glucose oxidation during clamp & $117 \pm 5^{\mathrm{a}}$ & $100 \pm 14^{\mathrm{a}}$ \\
NOGM in basal condition & $32 \pm 5$ & $27 \pm 5$ \\
NOGM during clamp & $229 \pm 28^{\mathrm{a}}$ & $\mathrm{ns}$ \\
\hline
\end{tabular}

Metabolic rates are expressed as milligram per milligram per minute squared $\left(\mathrm{mg} \mathrm{mg}^{-1} \mathrm{~min}^{-2}\right)$

Data are mean \pm SEM

${ }^{\mathrm{a}} \mathrm{p}<0.05$ vs basal

$G D R$ Glucose disposal rate, NOGM non-oxidative glucose metabolism, $n s$ not significant 
Fig. 1 Effect of insulin on insulin receptor tyrosine kinase activity (IRTK) (a), IRS-1-associated phosphoinositide 3-kinase (PI 3-kinase) activity (b), phosphorylation of Akt at Ser473 (c) and Thr308 (d), and Akt-1 (e) and Akt-2 (f) activities in skeletal muscle of six family members carrying the Arg1174Gln mutation in INSR and six control subjects. Representative immunoblots $(\mathbf{c}, \mathbf{d})$ for a control subject and an Arg1174Gln carrier are also shown. Measurements were performed in muscle biopsies obtained from $\mathrm{m}$. vastus lateralis during the basal (open bars) and insulin-stimulated (filled bars) steady-state periods of a 3-h euglycaemic-hyperinsulinaemic clamp at an insulin infusion rate of $40 \mathrm{mU} / \mathrm{m}^{2}$ per min. Data are mean \pm SEM. ${ }^{*} p<0.05$ for clamp vs basal values; $\uparrow p<0.05$ vs control subjects. $A U$ Arbitrary units a

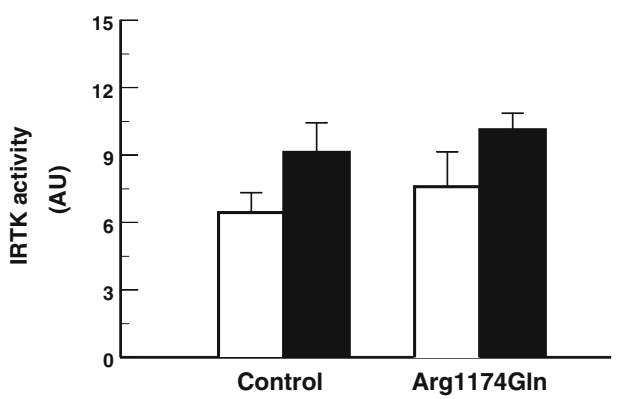

C
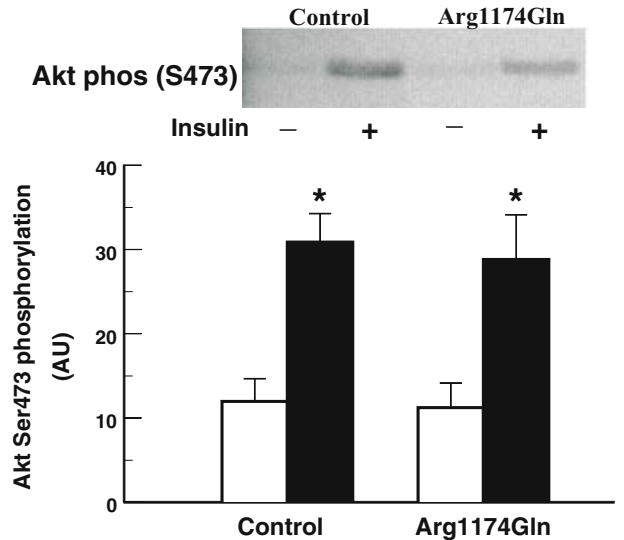

e

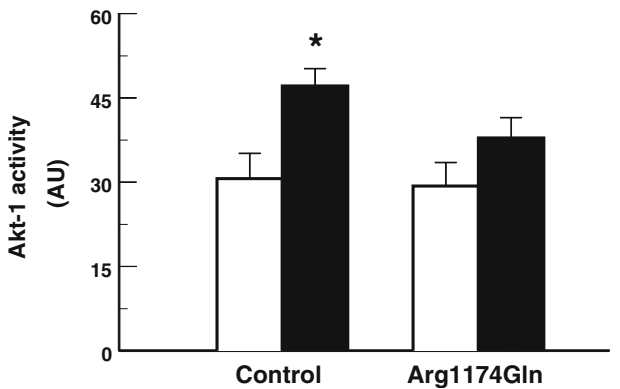

\section{b}

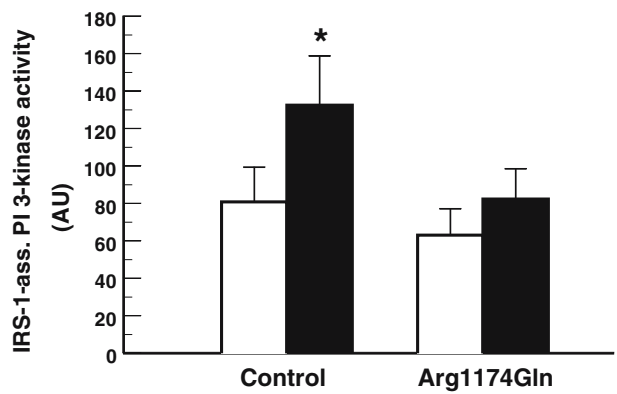

d

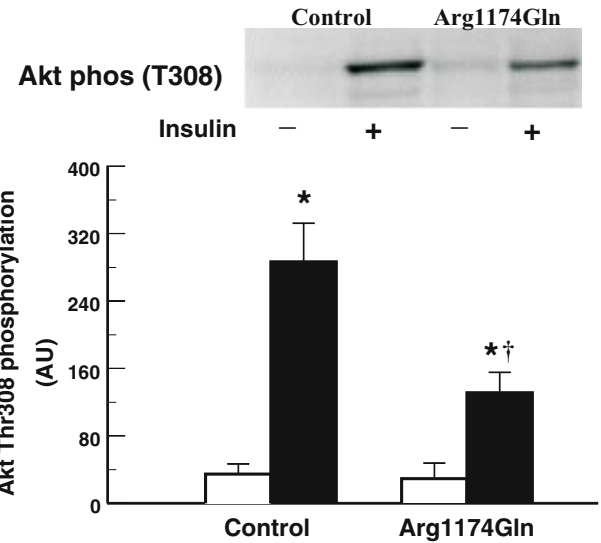

f

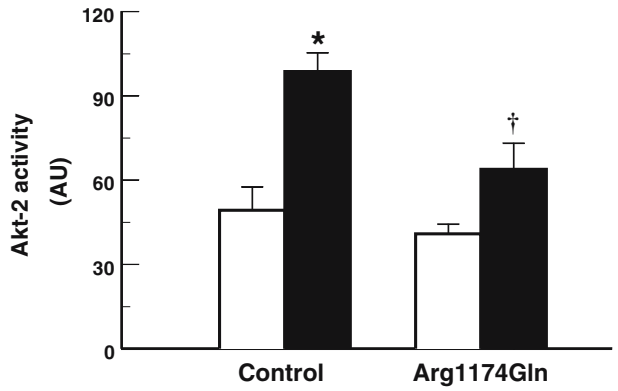

tended to decrease GSK-3 $\alpha$ activity $(p=0.11)$. Insulin infusion had no significant effect on GSK-3 $\beta$ activity in either of the groups.

Total glycogen synthase activity was similar in the two groups in the basal and the insulin-stimulated state (Fig. 2c). Insulin increased the I-form activity of glycogen synthase in both groups, but insulin-stimulated I-form activity of glycogen synthase was lower in the Arg1174Gln group compared with the control group (Fig. 2d).

Phosphorylation of glycogen synthase at regulatory sites

Insulin infusion reduced phosphorylation of glycogen synthase at sites $3 a+3 b$ by $\sim 50 \%$ in both groups (Fig. 3a), and there were no significant differences in phosphorylation at sites $3 a+3 b$ under basal or hyperinsulinaemic conditions. The phosphorylation of glycogen synthase either at site 2 alone or at sites $2+2 \mathrm{a}$ was unaffected by insulin infusion in the total population as well as in both the individual groups, and no differences between the groups were observed in the basal or the insulin-stimulated state (Fig. 3b,c).

Protein expression

The average insulin receptor protein content tended to be lower (by 36\%) in the Arg1174Gln group compared with control subjects $(p=0.09)$. We found no differences in the protein content of IRS-1, p85, Akt, GSK-3 $\alpha$, GSK-3 $\beta$, glycogen synthase or SLC2A4 protein between the groups (Fig. 4).

\section{Discussion}

The signalling properties of the naturally occurring Arg1174Gln mutation in INSR have been studied previous- 
Fig. 2 Effect of insulin on activity of glycogen synthase kinase- $3 \alpha($ GSK-3 $\alpha)($ a), GSK-3 $\beta$ activity (b), total glycogen synthase (GS) (c), and glycogen synthase as percentage of I-form activity (d) in skeletal muscle of six family members carrying the Arg1174Gln mutation in INSR and skeletal muscle of six control subjects. Measurements were performed in muscle biopsies obtained from $\mathrm{m}$. vastus lateralis during the basal (open bars)

and insulin-stimulated (filled bars) steady-state periods of a 3-h euglycaemic-hyperinsulinaemic clamp at an insulin infusion rate of $40 \mathrm{mU} / \mathrm{m}^{2}$ per min. Data are mean \pm SEM. ${ }^{*} p<0.05$ for clamp vs basal values; $\uparrow p<0.05$ vs control subjects a

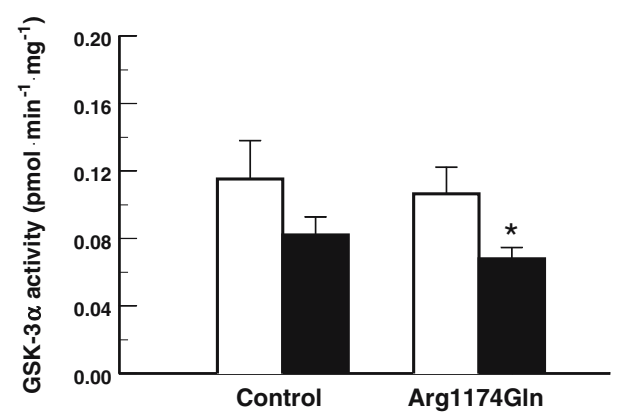

C

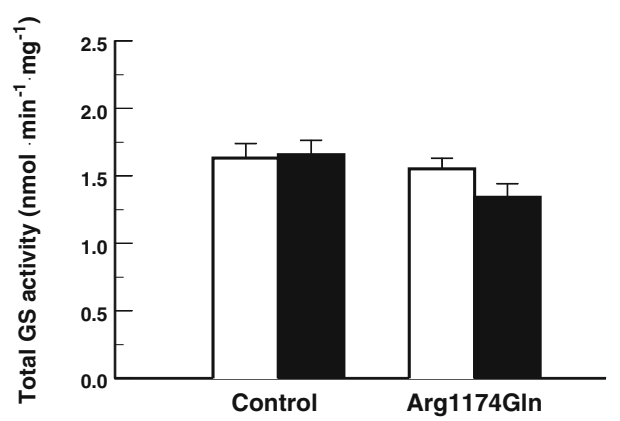

b

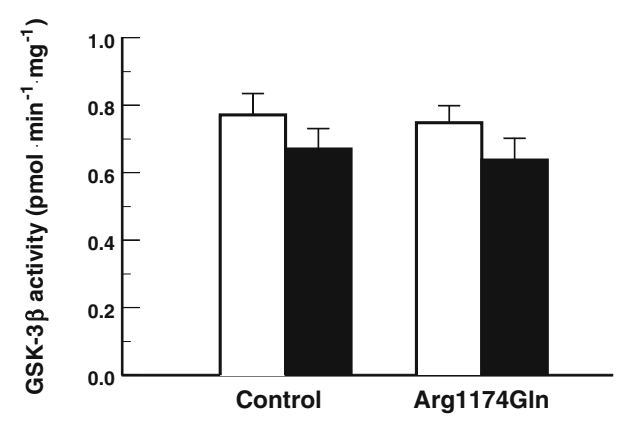

d

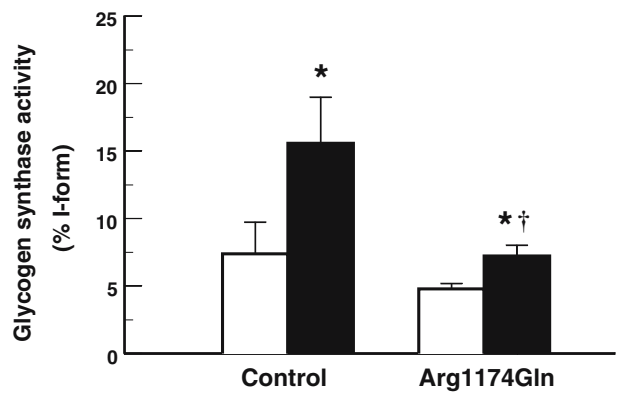

ly in Chinese hamster ovary $(\mathrm{CHO})$ cells transfected with mutant INSR [7, 19] and in patient lymphocytes transformed by Epstein-Barr virus [5]. In transfected cells, only receptors formed by two mutant $(\mathrm{mt})$ alleles $-\mathrm{mt} / \mathrm{mt}$ receptors - are synthesised, and the mutation is present in a homozygous state, which facilitates the interpretation of receptor function studies. In contrast, patient cells transformed by Epstein-Barr virus provide the possibility of studying the mutation in a heterozygous state similar to the situation in vivo, in which all three possible receptor species - $\mathrm{wt} / \mathrm{wt}$, wt/mt hybrid and $\mathrm{mt} / \mathrm{mt}$ receptors - are formed in an expected ratio of 1:2:1 [1,5]. In the present case-control study, we had the opportunity to investigate the functional consequences of a heterozygous mutation in $I N S R$ in skeletal muscle in vivo. We report functional impairment but also partial preservation of insulin action on insulin signalling in six family members harbouring the naturally occurring Arg1174Gln mutation of INSR.

Studies of the functional properties of the Arg1174Gln mutation have shown normal insulin binding and affinity to the receptor, but a $70-75 \%$ reduction in insulin-stimulated IRTK activity [5-7]. Furthermore, in CHO cell lines homozygous for the mutant INSR, stimulation with insulin in the physiological range $(1,000 \mathrm{pmol} / \mathrm{l})$ showed a pronounced inability to increase tyrosine phosphorylation of IRS-1, PI3K activity, SLC2A4 translocation and glycogen synthesis $[7,19]$. This suggests that homozygosity for the Arg1174Gln mutation in vivo would cause either extreme insulin resistance or be incompatible with life. In contrast, we report here that the presence of this mutant
INSR in its heterozygous form in vivo is associated with a surprisingly intact response to insulin administered in physiological concentrations. Although the ability of insulin to stimulate IRTK and PI3K activity was low and inconclusive in both groups, we found no significant differences in the activities of these kinases in the insulinstimulated state, and pooling of data from the Arg1174Gln carriers and controls in fact rendered the response to insulin significant for both kinases. More convincingly, we show that infusion of insulin at physiological rates in Arg1174Gln carriers was enough to increase Akt phosphorylation and activity, inhibit GSK-3 $\alpha$ activity, reduce phosphorylation of glycogen synthase at sites $3 a+3 b$, and stimulate G6P-independent glycogen synthase activity in vivo. Thus, in Arg1174Gln carriers the four-fold higher clamp insulin levels apparently compensate for the pronounced signalling defects found in vitro. This partial rescue of the action of insulin on glucose storage and in vivo insulin signalling by impaired insulin clearance is likely to involve an effect of higher insulin levels on the fraction of fully functional (wt/wt) insulin receptors. Additionally, insulin levels of $\sim 1,300 \mathrm{pmol} / 1$ may be enough to overcome the $\sim 10$-fold lower affinity of insulin for IGF-I and insulin/IGF-I hybrid receptors and evoke signalling through these receptors [24]. Reports of an increased number of insulin/IGF-I hybrid receptors in muscle of patients with chronic hyperinsulinaemia [25, 26] provide further support for a potential compensatory action of insulin through the IGF-I receptors in patients with mutant INSR. 


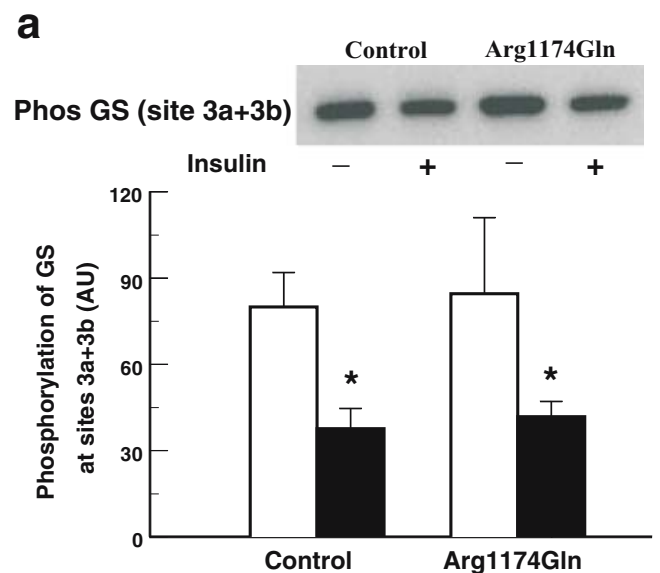

b
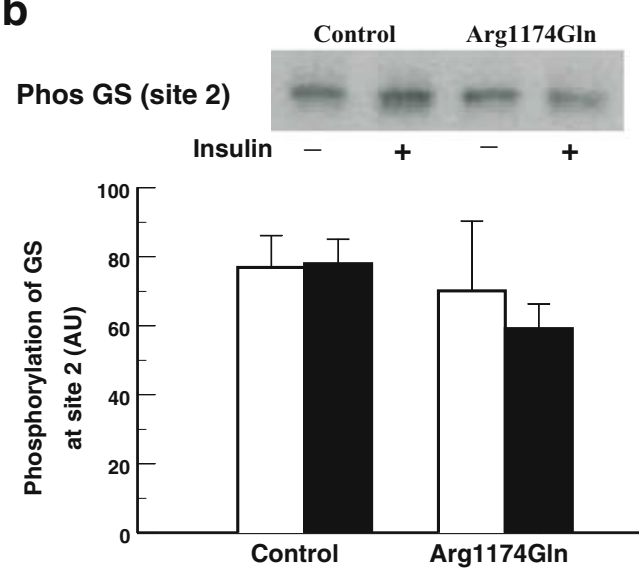

C
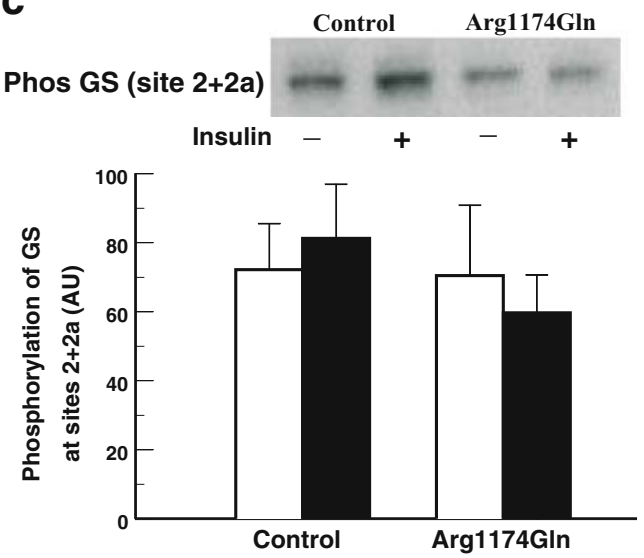

Fig. 3 The effect of insulin on phosphorylation of glycogen synthase (GS) at sites $3 a+3 b(a)$, site 2 alone (b) and sites $2+2 a$ (c) was determined in skeletal muscle of six family members carrying the Arg1174Gln mutation in INSR and skeletal muscle of six control subjects. Representative immunoblots $(\mathbf{a}-\mathbf{c})$ for a control subject and an Arg1174Gln carrier are also shown. Measurements were performed in muscle biopsies obtained from $\mathrm{m}$. vastus lateralis during the basal (open bars) and insulin-stimulated (filled bars) steady-state periods of a 3-h euglycaemic-hyperinsulinaemic clamp at an insulin infusion rate of $40 \mathrm{mU} / \mathrm{m}^{2}$ per min. Data are mean \pm SEM. ${ }^{*} p<0.05$ for clamp vs basal values. $A U$ Arbitrary units

Despite preservation of a significant effect of exogenous insulin on glucose uptake, glucose storage and most insulin signalling components in vivo, activation of PI3K and

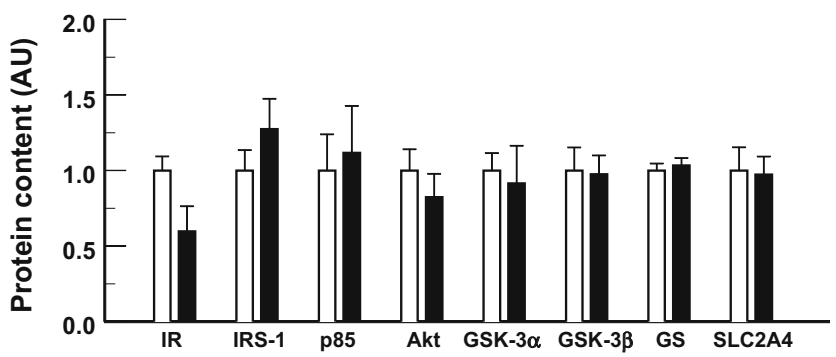

Fig. 4 Protein content of insulin signalling components in skeletal muscle of six family members carrying the Arg1174Gln mutation in INSR and in skeletal muscle of six control subjects. The protein levels were assessed by western blotting using muscle lysates of biopsies obtained from $\mathrm{m}$. vastus lateralis during basal conditions. The protein level in Arg1174Gln carriers was normalised to the level observed in the control subjects. Data are mean \pm SEM. $A U$ Arbitrary units, $I R$ insulin receptor

insulin-stimulated activities of Akt and glycogen synthase were modestly impaired in Arg1174Gln carriers compared with controls. This probably explains the moderate degree of insulin resistance. Thus, blunted activation of PI3K has been observed in several insulin-resistant states [14-16, 27]. Reduced Thr308 phosphorylation of Akt has been reported in obese non-diabetic subjects [28] and in nonobese patients with type 2 diabetes [29], but contrasts with findings in skeletal muscle of obese patients with type 2 diabetes and cultured muscle cells established from such patients $[10,15,17]$. The lower Thr308 phosphorylation of Akt may cause lower glucose transport in Arg1174Gln carriers, but was not responsible for the impaired insulin activation of glycogen synthase, because insulin-mediated inhibition of GSK-3 and subsequent dephosphorylation of glycogen synthase at sites $3 \mathrm{a}+3 \mathrm{~b}$ was normal.

The decrease of $\sim 50 \%$ in the phosphorylation of glycogen synthase at sites $3 a+3 b$ and the unchanged phosphorylation at sites $2+2 \mathrm{a}$ in response to insulin in both Arg1174Gln carriers and controls correspond to what has been reported previously in healthy subjects $[10,30]$ and provide further support for the notion that insulin activates glycogen synthase mainly by dephosphorylating sites $3 \mathrm{a}$, $3 \mathrm{~b}$ and $3 \mathrm{c}$ in vivo [9]. In patients with type 2 diabetes, impaired activation of glycogen synthase was explained by hyperphosphorylation at sites $2+2$ a despite normal insulinmediated dephosphorylation at sites $3 a+3 b$ [10]. In the Arg1174Gln carriers, blunted activation of G6P-independent glycogen synthase activity was not, however, associated with increased phosphorylation of sites $2+2 \mathrm{a}$. This suggests the possibility of increased phosphorylation at site $3 \mathrm{a}$ alone or at sites believed to be less important for glycogen synthase activity, such as sites $1 \mathrm{a}, 1 \mathrm{~b}, 3 \mathrm{c}, 4$ and 5 $[8,9]$. Alternatively, other post-translational modifications could be involved. Recently, it was reported that $O$-linked glycosylation of glycogen synthase induced by exposure to high concentrations of glucose or hexosamines could 
decrease glycogen synthase activity without changes in the phosphorylation state [31]. However, in the light of fasting plasma glucose and $\mathrm{HbA}_{1 \mathrm{c}}$ levels within the normal range, it seems unlikely that $O$-linked glycosylation plays a role in the observed blunted activation of glycogen synthase in Arg1174Gln carriers.

In agreement with a study of the Arg1174Gln mutation in patient lymphocytes transformed by Epstein-Barr virus [5], the number of insulin receptors in muscle tended to be lower (36\%) in Arg1174Gln carriers compared with control subjects. Studies of CHO cells cotransfected with wild-type and mutant INSR cDNA have shown that the Arg1174Gln mutation is more susceptible to proteasomal degradation and impairs the formation of $\mathrm{mt} / \mathrm{wt}$ hybrids, causing an increased fraction $(\sim 55 \%)$ of fully functional $(\mathrm{wt} / \mathrm{wt})$ receptors at the cell surface [32]. If this reflects the situation in vivo, this would explain the preserved insulin action mediated by impaired insulin clearance in spite of a small reduction in the total number of insulin receptors. In cell lines transfected with other kinase-deficient INSR mutations, accelerated receptor degradation has been reported to involve heat shock protein 90 (HSP90) [33], and recently the inhibition of HSP90 was shown to reduce the levels of functional non-mutated insulin receptors on the cell surface [34]. These studies suggest that HSP90 may serve to increase the amount of non-mutated relative to mutated insulin receptors. Interestingly, the level of HSP90 protein was recently reported to be increased in muscle of patients with type 2 diabetes [35]. Such an increase in HSP90 might antagonise the down-regulation of functional insulin receptors mediated by hyperinsulinaemia, and, as suggested by recent studies, preserve insulin signalling through Akt [36, 37]. Thus, increased levels of HSP90 in Arg1174Gln carriers could contribute to an increase in the relative amount of fully functional (wt/wt) insulin receptors, and hence the preservation of insulin action. This warrants further studies.

Using a euglycaemic-hyperinsulinaemic clamp, we provide evidence that the increased levels of insulin in Arg1174Gln carriers are caused by impaired insulin clearance. This effect, which is a known consequence of mutations in the IRTK domain [1], appears to play a major role in the partial preservation of the metabolic and signalling actions of insulin in muscle of patients harbouring the Arg1174Gln mutation. The data presented here provide no direct explanation for the coexistence of postprandial hypoglycaemia, but indirectly suggest the possibility that partial rescue of in vivo insulin signalling in other tissues, such as liver, beta cells and brain, may play a role. These findings may contribute to our understanding of the wide range of phenotypes observed in patients heterozygous for kinase-deficient INSR mutations, whereby some individuals develop syndromes of severe insulin resistance and type 2 diabetes whereas others, even in the same family, do not $[2,38]$. Whether the coexistence of moderate insulin resistance and postprandial hypoglycaemia rather than type 2 diabetes is specific to the Arg1174Gln mutation itself or is a consequence of this mutation only in the family reported here, due to other background factors, remains to be elucidated. However, INSR mutations are in fact uncommon as the cause of type 2 diabetes [2, 38], and mice with a heterozygous INSR mutation develop diabetes with a frequency varying between 5 and $10 \%[39,40]$. This suggests that heterozygous INSR mutations exert only a predisposing role in susceptibility to type 2 diabetes and that additional susceptibility genes and environmental factors are needed to give manifest diabetes.

In summary, we have demonstrated that insulin resistance in skeletal muscle of patients harbouring the Arg1174Gln mutation in the IRTK domain of the INSR gene is associated with some defects in insulin signalling, which could explain impaired insulin-stimulated glucose uptake and NOGM. However, these responses to exogenous insulin were to a large extent preserved, indicating the existence of compensatory mechanisms. Impaired insulin clearance, a built-in consequence of the Arg1174Gln mutation, seems to play a major role in these compensatory mechanisms by increasing insulin levels. Further exploration of insulin signalling events in muscle and other insulin target tissues are warranted in order to understand the coexistence of postprandial hypoglycaemia and insulin resistance in subjects harbouring this INSR mutation.

Acknowledgements L. Hansen, C. Olsen, P. Jensen and B. Bolmgren are acknowledged for skilled technical assistance. We thank D. G. Hardie at the University of Dundee for the kind donation of the anti-pGS site 2 and anti-pGS site $2+2$ a antibodies. The work was supported by grants from the Danish National Research Foundation (no. 504-14), the Media and Grants Secretariat of the Danish Ministry of Culture, the Danish Diabetes Association, the Novo Nordisk Foundation, the Danish Medical Research Council and by a Research and Technological Development Projects grant (QLG1-CT-200101488) funded by the European Commission. J. F. P. Wojtaszewski was supported by a Hallas Møller fellowship from the Novo Nordisk Foundation.

\section{References}

1. Taylor SI, Accili D (1996) Mutations in the genes encoding the insulin receptor and insulin receptor substrate-1. In: LeRoith D, Taylor SI, Olefsky JM (eds) Diabetes mellitus. A fundamental and clinical text, 2nd edn. Lippincott-Raven, Philadelphia, pp 575-583

2. Taylor SI (1992) Lilly Lecture: Molecular mechanisms of insulin resistance. Lessons from patients with mutations in the insulinreceptor gene. Diabetes 41:1473-1490 
3. Højlund K, Hansen T, Lajer M et al (2004) A novel syndrome of autosomal dominant hyperinsulinemic hypoglycemia linked to mutation in the human insulin receptor gene. Diabetes $53: 1592-1598$

4. Moller DE, Cohen O, Yamaguchi Y et al (1994) Prevalence of mutations in the insulin receptor gene in subjects with features of the type A syndrome of insulin resistance. Diabetes 43:247-255

5. Moritz W, Froesch ER, Boni-Schnetzler M (1994) Functional properties of a heterozygous mutation $(\operatorname{Arg} 1174 \rightarrow \mathrm{Gln})$ in the tyrosine kinase domain of the insulin receptor from a type A insulin resistant patient. FEBS Lett 351:276-280

6. Klein HH, Muller R, Vestergaard H, Pedersen O (1999) Implications of compound heterozygous insulin receptor mutations in congenital muscle fibre type disproportion myopathy for the receptor kinase activation. Diabetologia 42:245-249

7. Krook A, Moller DE, Dib K, O'Rahilly S (1996) Two naturally occurring mutant insulin receptors phosphorylate insulin receptor substrate-1 (IRS-1) but fail to mediate the biological effects of insulin. Evidence that IRS-1 phosphorylation is not sufficient for normal insulin action. J Biol Chem 271:7134-7140

8. Lawrence JC Jr, Roach PJ (1997) New insights into the role and mechanism of glycogen synthase activation by insulin. Diabetes 46:541-547

9. Cohen P, Alessi DR, Cross DA (1997) PDK1, one of the missing links in insulin signal transduction? FEBS Lett 410:3-410

10. Højlund K, Stæhr P, Hansen BF et al (2003) Increased phosphorylation of skeletal muscle glycogen synthase at $\mathrm{NH} 2$ terminal sites during physiological hyperinsulinemia in type 2 diabetes. Diabetes 52:1393-1402

11. Damsbo P, Vaag A, Hother-Nielsen O, Beck-Nielsen H (1991) Reduced glycogen synthase activity in skeletal muscle from obese patients with and without type 2 (non-insulin-dependent) diabetes mellitus. Diabetologia 34:239-245

12. Thorburn AW, Gumbiner B, Bulacan F, Wallace P, Henry RR (1990) Intracellular glucose oxidation and glycogen synthase activity are reduced in non-insulin-dependent (type II) diabetes independent of impaired glucose uptake. J Clin Invest 85:522-529

13. Nikoulina SE, Ciaraldi TP, Mudaliar S, Mohideen P, Carter L, Henry RR (2000) Potential role of glycogen synthase kinase-3 in skeletal muscle insulin resistance of type 2 diabetes. Diabetes 49:263-271

14. Cusi K, Maezono K, Osman A et al (2000) Insulin resistance differentially affects the PI 3-kinase- and MAP kinase-mediated signaling in human muscle. J Clin Invest 105:311-320

15. Kim YB, Nikoulina SE, Ciaraldi TP, Henry RR, Kahn BB (1999) Normal insulin-dependent activation of Akt/protein kinase B, with diminished activation of phosphoinositide 3-kinase, in muscle in type 2 diabetes. J Clin Invest 104:733-741

16. Beeson M, Sajan MP, Dizon M et al (2003) Activation of protein kinase C-zeta by insulin and phosphatidylinositol-3,4,5-(PO4)3 is defective in muscle in type 2 diabetes and impaired glucose tolerance: amelioration by rosiglitazone and exercise. Diabetes 52:1926-1934

17. McIntyre EA, Halse R, Yeaman SJ, Walker M (2004) Cultured muscle cells from insulin-resistant type 2 diabetes patients have impaired insulin, but normal 5-amino-4-imidazolecarboxamide riboside-stimulated, glucose uptake. J Clin Endocrinol Metab 89:3440-3448

18. Gaster M, Brusgaard K, Handberg A, Højlund K, Wojtaszewski JF, Beck-Nielsen H (2004) The primary defect in glycogen synthase activity is not based on increased glycogen synthase kinase-3alpha activity in diabetic myotubes. Biochem Biophys Res Commun 319:1235-1240

19. Krook A, Whitehead JP, Dobson SP et al (1997) Two naturally occurring insulin receptor tyrosine kinase domain mutants provide evidence that phosphoinositide 3-kinase activation alone is not sufficient for the mediation of insulin's metabolic and mitogenic effects. J Biol Chem 272:30208-30214

20. Højlund K, Wildner-Christensen M, Eshøj O et al (2001) Reference intervals for glucose, beta-cell polypeptides, and counterregulatory factors during prolonged fasting. Am J Physiol Endocrinol Metab 280:E50-E58

21. Vestergaard H, Lund S, Larsen FS, Bjerrum OJ, Pedersen O (1993) Glycogen synthase and phosphofructokinase protein and mRNA levels in skeletal muscle from insulin-resistant patients with non-insulin-dependent diabetes mellitus. J Clin Invest 91:2342-2350

22. Wojtaszewski JFP, Hansen BF, Kiens B, Richter EA (1997) Insulin signaling in human skeletal muscle: time course and effect of exercise. Diabetes 46:1775-1781

23. Richter EA, Mikines KJ, Galbo H, Kiens B (1989) Effect of exercise on insulin action in human skeletal muscle. J Appl Physiol 66:876-885

24. Soos MA, Field CE, Siddle K (1993) Purified hybrid insulin/ insulin-like growth factor-I receptors bind insulin-like growth factor-I, but not insulin, with high affinity. Biochem $\mathrm{J}$ 290:419-426

25. Federici M, Zucaro L, Porzio O et al (1996) Increased expression of insulin/insulin-like growth factor-I hybrid receptors in skeletal muscle of noninsulin-dependent diabetes mellitus subjects. J Clin Invest 98:2887-2893

26. Federici M, Lauro D, D'Adamo M et al (1998) Expression of insulin/ IGF-I hybrid receptors is increased in skeletal muscle of patients with chronic primary hyperinsulinemia. Diabetes 47:87-92

27. Dresner A, Laurent D, Marcucci M et al (1999) Effects of free fatty acids on glucose transport and IRS-1-associated phosphatidylinositol 3-kinase activity. J Clin Invest 103:253-259

28. Adams JM 2nd, Pratipanawatr T, Berria R et al (2004) Ceramide content is increased in skeletal muscle from obese insulin-resistant humans. Diabetes 53:25-31

29. Karlsson HK, Zierath JR, Kane S, Krook A, Lienhard GE, Wallberg-Henriksson H (2005) Insulin-stimulated phosphorylation of the Akt substrate AS160 is impaired in skeletal muscle of type 2 diabetic subjects. Diabetes 54:1692-1697

30. Poulsen P, Wojtaszewski JF, Petersen I et al (2005) Impact of genetic versus environmental factors on the control of muscle glycogen synthase activation in twins. Diabetes 54:1289-1296

31. Parker GJ, Lund KC, Taylor RP, McClain DA (2003) Insulin resistance of glycogen synthase mediated by o-linked $\mathrm{N}$-acetylglucosamine. J Biol Chem 278:10022-10027

32. Rau H, Kocova M, O'Rahilly S, Whitehead JP (2000) Naturally occurring amino acid substitutions at Arg1174 in the human insulin receptor result in differential effects on receptor biosynthesis and hybrid formation, leading to discordant clinical phenotypes. Diabetes 49:1264-1268

33. Imamura T, Haruta T, Takata $Y$ et al (1998) Involvement of heat shock protein 90 in the degradation of mutant insulin receptors by the proteasome. J Biol Chem 273:11183-11188

34. Saitoh T, Yanagita T, Shiraishi S et al (2002) Down-regulation of cell surface insulin receptor and insulin receptor substrate-1 phosphorylation by inhibitor of $90-\mathrm{kDa}$ heat-shock protein family: endoplasmic reticulum retention of monomeric insulin receptor precursor with calnexin in adrenal chromaffin cells. Mol Pharmacol 62:847-855

35. Højlund K, Wrzesinski K, Larsen PM et al (2003) Proteome analysis reveals phosphorylation of ATP synthase beta-subunit in human skeletal muscle and proteins with potential roles in type 2 diabetes. J Biol Chem 278:10436-10442

36. Sato S, Fujita N, Tsuruo T (2000) Modulation of Akt kinase activity by binding to Hsp90. Proc Natl Acad Sci USA 97:10832-10837 
37. Takahashi S, Mendelsohn ME (2003) Synergistic activation of endothelial nitric-oxide synthase (eNOS) by HSP90 and Akt: calcium-independent eNOS activation involves formation of an HSP90-Akt-CaM-bound eNOS complex. J Biol Chem 278:30821-30827

38. Kitamura T, Kahn CR, Accili D (2003) Insulin receptor knockout mice. Annu Rev Physiol 65:313-332
39. Kido Y, Burks DJ, Withers D et al (2000) Tissue-specific insulin resistance in mice with mutations in the insulin receptor, IRS-1, and IRS-2. J Clin Invest 105:199-205

40. Bruning JC, Winnay J, Bonner-Weir S, Taylor SI, Accili D, Kahn CR (1997) Development of a novel polygenic model of NIDDM in mice heterozygous for IR and IRS-1 null alleles. Cell 88:561-572 